\title{
The functional role of protein in the organization of bacteriochlorophyll $c$ in chlorosomes of Chloroflexus aurantiacus
}

\author{
Georg NIEDERMEIER ${ }^{1}$, Hugo SCHEER ${ }^{2}$ and Reiner G. FEICK ${ }^{1}$ \\ 1 Max-Planck-Institut für Biochemie, Martinsried, Federal Republic of Germany \\ 2 Botanisches Institut, Universität München, Federal Republic of Germany
}

(Reccived July 25/October 21, 1991) - EJB 910985

\begin{abstract}
The preparation of five different fractions containing bacteriochlorophyll (Bchl) $c$ and their absorption and circular dichroic properties have been described. The fractions investigated were purified chlorosomes, proteolytically modified chlorosomes, chlorosomes treated with lithium dodecyl sulfate (LDS) which were subsequently subjected to size-exclusion chromatography, in vitro Bchl $c$ aggregates and, additionally, the so-called GEF chlorosomes [prepared according to Griebenow and Holzwarth (1989) Biochim. Biophys. Acta 973, 235-240]. Proteolysis of chlorosomes caused a 35$40 \%$ decrease in absorption intensity, a $6-8 \mathrm{~nm}$ blue shift of the $740-\mathrm{nm}$ peak and, in particular, a drastic increase of rotational strength as revealed by $C D$ spectroscopy. Although oligomeric Bchl $c$ aggregates and LDS-treated chlorosomes had absorption characteristics similar to Bchl $c$ in vivo, the data clearly indicated that protein, perhaps the chlorosome-specific $M_{\mathrm{r}}-3700$ polypeptide, was involved in the organization of Bchl $c$ in chlorosomes from $C$. aurantiacus. Furthermore, the results showed that the LDS-treated chlorosome fraction was most likely comprised of a micellar complex of Bchl $c$ with LDS which represented an entity entirely different from chlorosomes.
\end{abstract}

The antenna system of the green photosynthetic bacterium Chloroflexus aurantiacus is composed of three pigment complexes which are located in two different subcellular structures. The bacteriochlorophyll (Bchl) $a$ antenna complex, B $808-866$, surrounds the reaction center in the cytoplasmic membrane. The major antenna pigment in $C$. aurantiacus, Bchl $c$, is located in chlorosomes and absorbs at $740 \mathrm{~nm}$ (B 740) $[1-3]$. Chlorosomes are oblong bodies of about $100 \times 30 \times 12 \mathrm{~nm}^{3}$ and are firmly attached to the inner side of the cytoplasmic membrane. The chlorosome is surrounded by a 3-5-nm thick envelope $[4-6]$.

In addition to the Bchl-containing $B \mathbf{7 4 0}$ complex, a small but significant amount of Bchl $a$ absorbing at $790 \mathrm{~nm}$ (B 790 ) is part of the chlorosome. This photochemically inactive pigment form is thought to be part of a so-called baseplate which functionally and physically attaches the chlorosome to the cytoplasmic membrane $[1,2,4,7]$. Due to this energetic and structural linkage, photons absorbed by $B 740$ in chlorosomes proceed efficiently, within $10-15 \mathrm{ps,}$ to B 790 and, subsequently, within $30-50$ ps to the B $808-866$ complex in the cytoplasmic membrane. Energy transfer from the chlorosomal Bchl $c$ to the Bchl $a$ (B 866) at physiological temperatures (above $40^{\circ} \mathrm{C}$ ) has been determined to occur with $70 \%$ to nearly $100 \%$ efficiency [ $7-14]$.

Purified chlorosomes isolated according to [2] were comprised of three major polypeptides with apparent $M_{\mathrm{r}}$ of 18000 ,

Correspondence to R. Feick, Max-Planck-Institut für Biochemie, Am Klopferspitz, W-8033 Martinsried, Federal Republic of Germany Abbreviations. Bchl, bactenochlorophyll; LDS, lithium dodecyl sulfate; GEF, gel electrophoretic filtration.
11000,3700 (as determined by SDS/PAGE) and one polypeptide $\left(M_{\mathrm{r}} 5800\right)$ present in small amounts. From attempts to isolate a spectrally intact $\mathrm{Bchl} c$ protein complex and topographical studies, it was deduced that the $M_{\mathrm{r}}-18000$ and $M_{\mathrm{r}}-11000$ proteins were constituents of the chlorosome envelope while the $M_{\mathrm{r}}-3700$ polypeptide was tentatively designated as the antenna Bchl-c-binding protein [2,3]. From these studies, it was concluded that the smallest functional B 740 complex was composed of two copies of the $M_{r}-3700$ polypeptide and $10-16 \mathrm{Bchl} c$ molecules. This proposed arrangement was in complete accord with results from EPR measurement on chlorosomes and oligomeric Bchl $c$ in organic solvents $[7,15]$.

Subsequently, the primary structure of the $M_{\mathrm{r}}-3700$ protein was determined from which a relative molecular mass of 5592 was calculated [16]. Based upon existing data, the authors proposed a chromophore-protein model with seven Bchl $c$ molecules bound to one $M_{\mathrm{r}}-3700$ protein in an $\alpha$-helical conformation. Aggregates of these smallest structural units were thought to comprise the cylindrical elements observed by electron microscopy in the chlorosome interior [4].

The role of proteins as essential components for the functional in vivo organization of antenna pigments from various photosynthetic organisms has been demonstrated numerous times (for reviews see [17-19]). The importance of proteins could not only be demonstrated by crystallization studies [20] but could also be directly probed by the susceptibility of absorption bands of antenna pigment complexes to proteolytic treatment $[21-24]$. On the other hand, there is an equal number of reports demonstrating that Bchl $a$, bacteriophytin $a$, chlorophyll $a$ or pheophytin a formed oligomers in nonpolar 
organic solvent/water mixtures, in formamide/water solutions and in aqueous detergent solutions and had spectral features similar to the in vivo spectra of these pigments (for recent reviews see $[25,26])$.

When concentrated solutions of purified Bchl $c$ (in $\mathrm{CCl}_{4}$, $\mathrm{CH}_{2} \mathrm{Cl}_{2}$ ) were diluted with hexane, Bchl $c$ oligomers with spectral properties closely resembling those of native chlorosomes formed spontaneously [15.27-29]. Hence, Bchl $c$ oligomers without the direct involvement of protein were considered to be the in vivo organization of pigment in chlorosomes. This idea was consistent with the unusually high $\mathrm{Bchl} c /$ protein ratio observed in subchlorosomal fractions [3].

Recently a preparation of a Bchl-c-containing fraction has been described which, according to the authors' interpretation, contained baseplate free, i.e. Bchl-a-(B 790)-free chlorosomes of $C$. aurantiacus [30]. The retention of native absorption properties, despite the absence of protein in the isolated fraction, was taken as strong evidence for a proteinfree chromophore aggregate in chlorosomes. Contradicting results, however, have been reported by Eckhardt et al. [31]. Following the same isolation protocol, Eckhardt et al. obtained further evidence for a structural and functional role of the $M_{\mathrm{r}}-3700$ polypeptide in the Bchl $c$ (B 740) complex of $C$. aurantiacus chlorosomes.

The results presented in this study clearly corroborate earlier findings that protein does play a functional role in the organization of Bchl $c$ in chlorosomes of $C$. aurantiacus. Furthermore, the data strongly indicate that the previously described free chlorosome preparation baseplate (B 790) consists most likely of Bchl- $c$-detergent micelles.

\section{MATERIALS AND METHODS}

\section{Biochemicals}

Enzymes were purchased from either Boehringer Mannheim (Mannheim, FRG) or Sigma Chemie (Deisenhofen, FRG). All other chemicals were the highest grade available.

\section{Growth conditions and chlorosome isolation}

Cultivation of $C$. aurantiacus strain $\mathrm{J} 10-\mathrm{fl}$ and isolation of the whole membrane fraction containing cytoplasmic membranes and chlorosomes were performed as reported previously [2]. Phenylmethylsulfonyl fluoride $(2 \mathrm{mM})$ was added prior to and after cell breakage and after each subsequent fractionation step. Chlorosomes were isolated according to Feick and Fuller [3] by repeated sucrose density gradient centrifugation in the absence of Miranol. If not mentioned otherwise, chlorosomes were isolated from cells grown under 'medium light' conditions (approximately $100-300 \mathrm{~W} \mathrm{~m}^{-2}$ ). 'Low light' chlorosomes refer to chlorosomes isolated from cells grown under $10-30 \mathrm{~W} \mathrm{~m}^{-2}$. Throughout all experiments $20 \mathrm{mM}$ Tris $/ \mathrm{Cl} \mathrm{pH} 8.0$ was used as the buffer.

\section{Proteolytic treatment of chlorosomes}

To a suspension of chlorosomes with $A_{740 \mathrm{~nm}}=60(\approx 6 \mathrm{mg}$ protein $/ \mathrm{ml}$ ), thermolysin was added to a final concentration of $1.25 \mathrm{mg} / \mathrm{ml}$ and incubated at various temperatures. For each time point, two aliquots were taken. One aliquot was used immediately to record the absorption spectrum while the second aliquot was precipitated with ice-cold trifluoroacetic acid ( $10 \%$ final concentration). After centrifugation, the pellet was washed twice with $1 \mathrm{ml}$ acetone to remove pigments.
Control experiments with radioactively labeled chlorosomes (see below) showed that no protein was lost during the precipitation and acetone washings. The pellet was solubilized as described in [32] ('sample treatment 1').

\section{Preparation of LDS-treated chlorosomes}

To a suspension of isolated chlorosomes adjusted to $A_{740 \mathrm{~nm}}=25$, LDS was added to a final concentration of $0.8 \%$ and stirred for $2 \mathrm{~h}$ at room temperature. After centrifugation for $90 \mathrm{~min}$ at $100000 \times \mathrm{g}$, the supernatant was concentrated by ultrafiltration (Amicon filtration cell, YM 30 filter) and subjected to size-exlusion chromatography on a Superose 12 (Pharmacia-LKB) column equilibrated with Tris buffer containing $0.3 \%$ LDS (flow rate $0.2 \mathrm{ml} / \mathrm{min}$ ). In some experiments LDS was substituted with SDS or sodium lauroyl sarcosine. For preparing GEF 'chlorosomes' the protocol of [30] was strictly followed in every aspect (e.g. buffer, solubilization and electrophoretic conditions).

\section{Radiolabeling of chlorosomes}

Chlorosomal proteins were labeled by reductive alkylation with $\left[{ }^{14} \mathrm{C}\right]$ formaldehyde in the presence of sodium cyanoborohydride according to [33]. $10 \mathrm{ml}$ of a chlorosome suspension $\left(A_{740 \mathrm{~nm}}=70\right)$ in $20 \mathrm{mM}$ sodium phosphate $\mathrm{pH} 7.5$ was treated for $24 \mathrm{~h}$ with $100 \mu \mathrm{Ci}\left[{ }^{14} \mathrm{C}\right]$ formaldehyde in the presence of $0.3 \%$ sodium cyanoborohydride. Unbound radioactivity was removed by sedimenting the chlorosomes twice at $105000 \times g$ for $90 \mathrm{~min}$. The resulting pellet was resuspended in Tris buffer and subsequently used for proteolytic modification.

\section{SDS/polyacrylamide gel electrophoresis}

Gel electrophoretic separation of proteins was performed using the buffer system of [34] in a linear $11.5-16.5 \%$ acrylamide and $0.3-0.8 \% \quad N, N^{\prime}$-methylene bisacrylamide gradient gel. Further details and sample solubilization methods are described in [32] and [35].

\section{Quantitation of proteins after SDS/PAGE}

Quantitation of radioactive proteins in SDS/polyacrylamide gels was done as described in [32], 'method 1'. Coomassie-blue-stained nonradioactive proteins were eluted from gel pieces by incubation in $1 \mathrm{ml}$ of an organic solvent mixture containing $50 \%$ formic acid, $25 \%$ acetonitrile, $15 \%$ 2-propanol and $10 \%$ water for $48 \mathrm{~h}$ at room temperature [32]. The relative protein content was determined by the absorbance of the eluted Coomassie blue dye at $600 \mathrm{~nm}$. Both methods have previously been shown to facilitate quantitative elution and quantitation of proteins from polyacrylamide gels [32].

\section{Preparation of oligomeric Bchl $c$}

Bchl $c$ was extracted and isolated by reverse-phase highperformance liquid chromatography as described [28] except that the last purification step was omitted. Dried Bchl $c$ was stored at $-20^{\circ} \mathrm{C}$. Oligomers of Bchl $c$ were obtained by diluting $50 \mu \mathrm{l}$ of a concentrated methanolic pigment solution with $1 \mathrm{ml}$ Tris buffer and incubation for $30 \mathrm{~min}$ at $60^{\circ}$.

\section{Spectroscopic measurements}

Absorption spectra were recorded on a Shimadzu UV 160 or a Perkin Elmer 350 spectrophotometer. Circular dichroic 


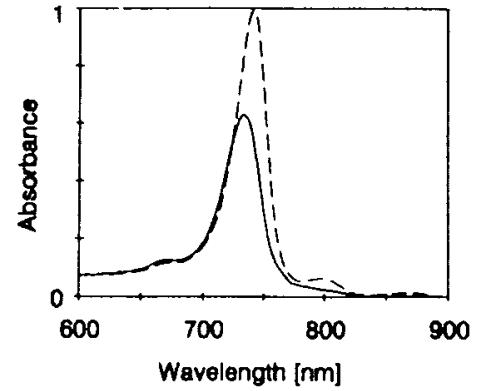

Fig. 1. Near-infrared absorption spectra of isolated 'medium light' chlorosomes before and after thermolysin treatment. (-- -$)$ Zero time $\left(\lambda_{\max } 741 \mathrm{~nm}\right) ;(-)$ after $90 \mathrm{~min}\left(\lambda_{\max } 733 \mathrm{~nm}\right)$ of treatment with $200 \mu \mathrm{g}$ thermolysin/mg chlorosome protein at $55^{\circ} \mathrm{C}$.

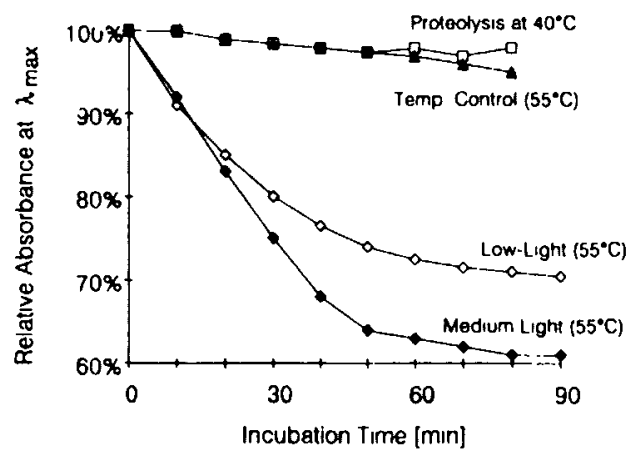

Fig. 2. Effect of thermolysin treatment on the absorption intensity at $740 \mathrm{~nm}$ in isolated chlorosomes. ( ) 'Medium light' chlorosomes digested at $55 \mathrm{C} ;(\diamond)$ 'low light' chlorosomes digested at $55^{\prime} \mathrm{C} ;(\square)$ 'medium light' chlorosomes digested at $40^{\prime \prime} \mathrm{C}$; $(\Delta)$ 'medium light' chlorosomes without thermolysin at $55^{\circ} \mathrm{C}$ (temperature control); $200 \mathrm{\mu g}$ thermolysin was used/mg chlorosome protein. Each line represents the results of at least six experiments with approximately $\pm 8 \%$ deviation.

spectra were measured with a dichrograph $\mathrm{V}$ (Jobin-Yvon) spectropolarimeter with solutions of $A_{740 \mathrm{~nm}}=$ of $0.5-0.8$ $(d=1 \mathrm{~cm})$.

\section{RESULTS}

\section{Proteolysis of chlorosomes}

The contribution of proteins to the native absorption properties of antenna and reaction center complexes could be readily assessed by the susceptibility of absorbance bands to proteolytic modification. Proteases most effective in altering the absorption properties of chlorosomes were proteinase $\mathrm{K}$, subtilisin, chymotrypsin and thermolysin. Although all four enzymes yielded essentially the same resuits, thermolysin was found to be most suitable due to the simplicity in controlling and terminating the enzymatic reaction. In addition, the temperature optimum of the enzyme was close to the optimum growth temperature of $C$. aurantiacus.

Thermolysin treatment of chlorosomes for $90 \mathrm{~min}$ at $55^{\circ} \mathrm{C}$ caused two pronounced changes in the Bchl $c 740-\mathrm{nm}$ absorption band: (a) a $35-40 \%$ decrease of absorption intensity and (b) a 6-8-nm blue shift (from $741 \mathrm{~nm}$ ) to $733 \mathrm{~nm}$ (Figs 1 3). The kinetics of the proteolysis-associated blue wavelength shift was similar to the kinetics of the $740-\mathrm{nm}$ absorption decrease. The Bchl $a$ absorption at $790 \mathrm{~nm}$ also disappeared.

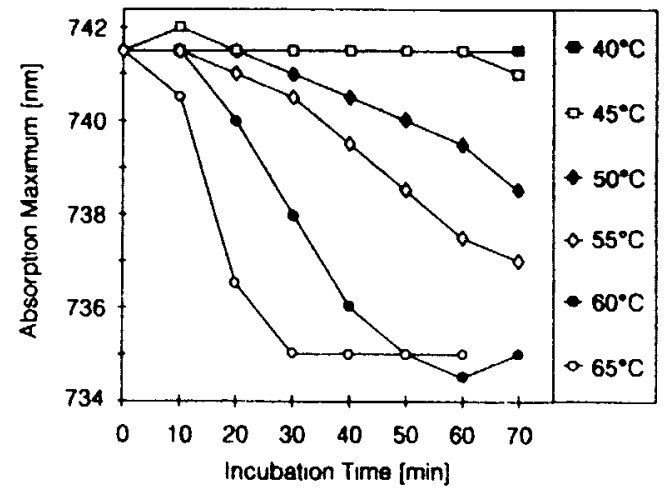

Fig. 3. Absorption shift of the near-infrared $\lambda_{\text {max }}$ of chlorosomes caused by thermolysin treatment ( $200 \mu \mathrm{g}$ thermolysia/mg chlorosome protein) at different temperatures.

Chlorosomes from cells grown under 'medium light' or 'high light' intensities $\left(>300 \mathrm{~W} \mathrm{~m}^{-2}\right.$ ) were more susceptible to a proteolysis-induced absorption decrease than chlorosomes isolated from 'low light' cells (Fig. 2). No significant decrease in $A_{740 \mathrm{~nm}}$ was observed when the thermolysin treatment was carried out at $40^{\circ} \mathrm{C}$ or when the chlorosomes were incubated at $55^{\circ} \mathrm{C}$ in the absence of protease; these changes never exceeded $5 \%$ (Fig. 2).

Changes in the protein composition of chlorosomes during thermolysin treatment were analyzed by SDS/PAGE (Figs 4 and 5). Under conditions where no thermolysin-induced changes in the 740-nm absorption intensity occurred $\left(37^{\circ} \mathrm{C}\right)$, the amount of $M_{\mathrm{t}}-3700$ protein (which has been tentatively assigned as the Bchl-c-binding protein) decreased by only $15 \%$ (Figs $4 \mathrm{~B}, 5$ ). In contrast, the $M_{\mathrm{t}}-18000$ and $M_{\mathrm{r}}-11000$ polypeptides were degraded within $20 \mathrm{~s}$ after the addition of protease. At $55^{\circ} \mathrm{C}$, however, the $\boldsymbol{M}_{\mathrm{r}}-3700$ polypeptide could be digested to about $10 \%$ of its original relative content (Figs 4A, 5). The kinetics of this disappearance generally paralleled that of the spectral blue shift of the 740-nm absorption band upon thermolysin treatment.

\section{Detergent treatment}

Since these results clearly implicated the functional importance of protein for the in vivo absorption characteristics of chlorosomes, we subsequently attempted to isolate a functional B 740 pigment-protein complex from chlorosomes. Among 25 detergents tested, the best results were obtained with a few anionic detergents such as LDS, SDS and sodium lauroyl sarcosinate. All three detergents allowed the preparation of coloured fractions with characteristic in vivo Bchl $c$ absorption at $740 \mathrm{~nm}$ and with little 'monomeric' Bchl $c$ absorbing at $660 \mathrm{~nm}$. No B 790 absorption could be observed. Control experiments clearly demonstrated the lability of B 790 against these detergents (e.g. treatment of chlorosomes with $0.5 \% \mathrm{LDS}$ for 20 min caused the complete disappearance of the 790-nm absorbance).

The supernatant of LDS-treated chlorosomes (see Methods), which contained all four major chlorosome polypeptides, was subjected to size-exclusion chromatography on a Superose 12 column (Fig. 6, lane C). Almost $80 \%$ of Bchl $c$ absorbing at $740 \mathrm{~nm}$ (Fig. 9A) was found in fraction 1 (Fig. 6, lane 1); lower amounts of this Bchl form were found in fractions 2 and 3 (Fig. 6). Monomeric Bchl $c$ (absorbance maximum at $666 \mathrm{~nm}$ ) eluted in fraction 4 . Gel electrophoretic 
A

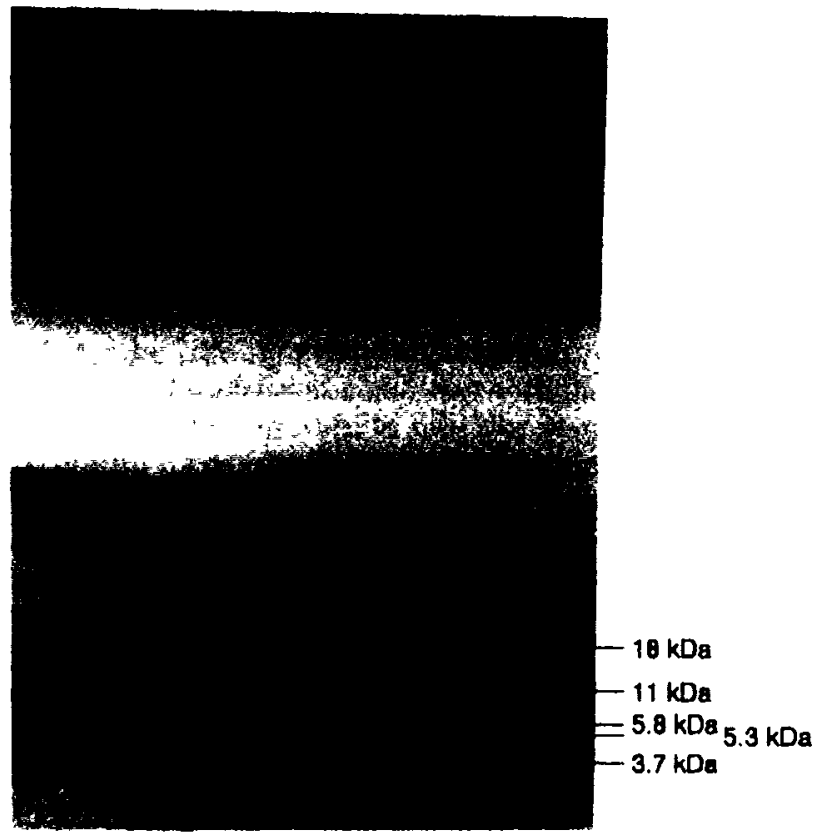

B

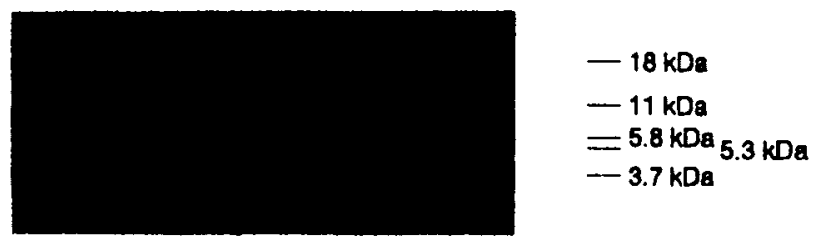

\section{$\begin{array}{llllllll}0.5 & 15 & 30 & 45 & 60 & 75 & 90 & \mathrm{C}\end{array}$ Incubation time [min]}

Fig. 4. Polypeptide profiles of thermolysin-treated 'medium light' chlorosomes after different incubation times at $A\left(55^{\circ} \mathrm{C}\right)$ and $B\left(37^{\circ} \mathrm{C}\right)$ after SDS/PAGE. (200 $\mu \mathrm{g}$ thermolysin/mg chlorosome protein). The parallel decrease in absorbance is shown in Fig. 2. Control chlorosomes (no protease added) are indicated by $\mathrm{C}$; this fraction contained minor impurities of an $M_{\mathrm{r}}-5300$ polypeptide which is characteristic of the B $808-866$ complex. The high-molecular-mass protein band is thermolysin.

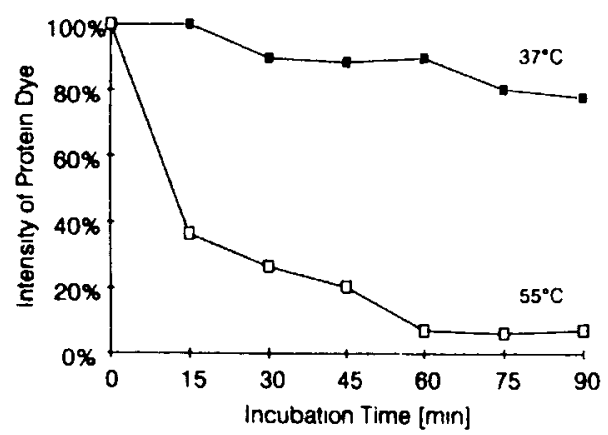

Fig. 5. Relative content of $M_{\mathrm{r}}-3700$ polypeptide after thermolysin treatment of chlorosomes. Experimental conditions as in Fig. 4.

analysis revealed that, despite the native absorption properties of Bchl $c$ in fraction 1 (subsequently referred to as 'LDStreated chlorosomes') no significant amount of protein was detected in this fraction (Fig. 6, lane 1). The characteristic chlorosomal proteins were found in fractions 2 and 3 . The latter fraction was relatively enriched in the $M_{\mathrm{r}}-3700$ polypep-

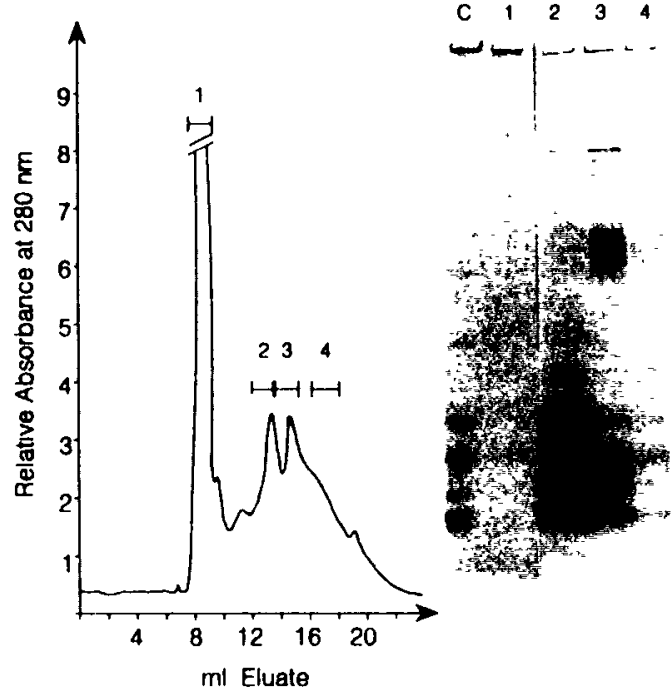

Fig. 6. Size-exclusion chromatography of supernatant of LDS-treated chlorosomes. The polypeptide profile of four fractions after SDS/ PAGE is shown in the insert. Isolated chlorosomes are indicated by C.

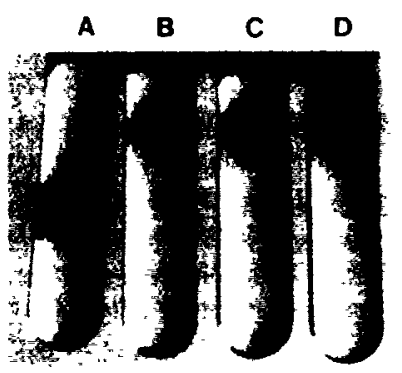

Fig. 7. Isopycnic gradient centrifugation of (A) intact chlorosomes, (B) thermolysin-treated chlorosomes, (C) GEF 'chlorosomes' and (D) supernatant of LDS-treated chlorosomes.

tide; this polypeptide was also present in traces in late-eluting material. The absorption spectra of the supernatant of LDStreated chlorosomes, fraction 1 and GEF 'chlorosomes', were essentially the same (Fig. 9 A).

Since this result, i.e. in vivo Bchl $c$ absorption characteristics despite the absence of protein, contradicted the results of the proteolytic experiments, we assumed that LDS treatment of chlorosomes caused the formation of Bchl-c-detergent micelles having spectral properties closely resembling those of native chlorosomes. This idea was supported by the results of the following experiments.

The buoyant density of 'medium light' chlorosomes, thermolysin-digested chlorosomes, fraction 1 of Superose chromatography and GEF 'chlorosomes' was determined by isopycnic sucrose gradient centrifugation. The density of the intact chlorosomes was significantly higher $\left(\varrho\right.$ at $20^{\circ} \mathrm{C}=$ $1.13 \mathrm{~g} / \mathrm{cm}^{3}$ ) than that of digested chlorosomes, fraction 1 and, in comparison to that of GEF 'chlorosomes' (all $\varrho$ at $20^{\circ} \mathrm{C}=$ $1.06 \mathrm{~g} / \mathrm{cm}^{3}$; Fig. 7). The density of the three latter fractions did not depend on the presence of LDS in the sucrose solution.

When isolated chlorosomes were treated with $0.8 \%$ Lubrol PX and then subjected to ultracentrifugation, a supernatant with characteristic monomeric Bchl $c$ absorption properties (Fig. 8, solid line) was obtained. Addition of LDS $(0.3 \%$ final 


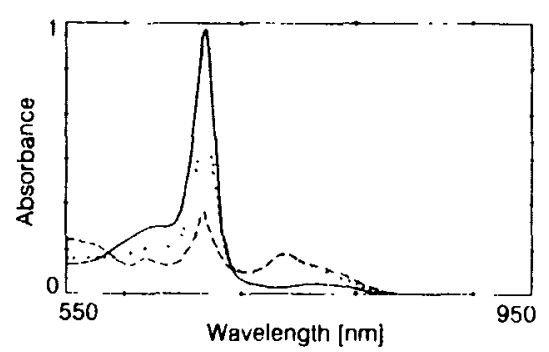

Fig. 8. Near-infrared absorption spectra of $(-)$ supernatant after solubilization of chlorosomes with $0.8 \%$ Lubrol PX, $(\cdots) 30 \mathrm{~min}$ and - - ) $120 \mathrm{~min}$ after the addition of LDS to a concentration of $0.3 \%$ to this Lubrol supernatant at room temperature.

concentration) led, over a period of 30-180 min at room temperature, to a drastic reduction in the absorbance intensity of the monomeric Bchl $c$ peak at $666 \mathrm{~nm}$ and a slow increase in the absorbance around $740-750 \mathrm{~nm}$ (Fig. 8, dashed line). After $3 \mathrm{~h}$ a small yet distinct peak at $740 \mathrm{~nm}$ was observed. This observation further substantiated the idea that an interaction of LDS with Bchl $c$ could cause the bathochromic absorption shift of Bchl c in vitro, probably by inducing aggregate formation.

To verify further that $\mathrm{Bchl}-\mathrm{c}-\mathrm{LDS}$ complexes are the origin of the in vitro absorbance red shift, we tried to generate the 740-nm absorbance band from a monomeric $\mathrm{Bchl} c$ solution (absorbance maximum at $666 \mathrm{~nm}$ ). An aliquot of a methanolic solution of purified Bchl $c$ was diluted with $20 \mathrm{mM}$ Tris, $0.4 \%$ LDS $\mathrm{pH} 8.0$ and incubated for $30 \mathrm{~min}$ at $50^{\circ} \mathrm{C}$. This procedure resulted in a reduction of the monomeric 666nm band intensity to about $25 \%$ of the original intensity and was accompanied by the appearance of an absorption band at $733 \mathrm{~nm}$ (similar to spectrum shown at the bottom of Fig. 9 A). An almost $100 \%$ conversion into the $733-\mathrm{nm}$ form could be achicved if LDS was omitted (Fig. 9A, bottom spectrum). This experiment also provided an explanation of why thermolysin treatment of chlorosomes did not cause a complete loss of absorption at $740 \mathrm{~nm}$ and a shift to only $734 \mathrm{~nm}$ rather than to $666 \mathrm{~nm}$.

\section{Circular dichroism}

Since circular dichroic (CD) spectroscopy can be a sensitive technique for probing the strength of intermolecular dipole coupling among pigments and, hence, their geometry, the Bchl-c-containing fractions (purified chlorosomes, digested chlorosomes, LDS-treated chlorosomes, Bchl $c$ in Tris buffer, and, for comparison, GEF chlorosomes) were further characterized by this technique. All CD spectra recorded from Bchlc-containing fractions prepared from various cell batches showed consistently the same qualitative features: an $\mathrm{S}$-shaped $\mathrm{CD}$ band with a positive maximum at $760 \mathrm{~nm}$, a negative maximum at $728 \mathrm{~nm}$ and with zero crossings between $742 \mathrm{~nm}$ and $733 \mathrm{~nm}$ which corresponded to the absorption maximum of the respective fractions (Fig. 9B). This characteristic feature reflected excitonic coupling of strongly interacting Bchl $r$ molecules. The differences were more pronounced in the spectral region between $400-500 \mathrm{~nm}$. This region contains contributions from Bchl $c$ Soret and, around $520 \mathrm{~nm}$, from carotenoid transitions. The latter are absent in the Bchl $c$ in Tris buffer.

In spite of the qualitative similarities in the near-infrared, there are striking quantitative differences between the five different fractions. This includes the magnitude of the integral
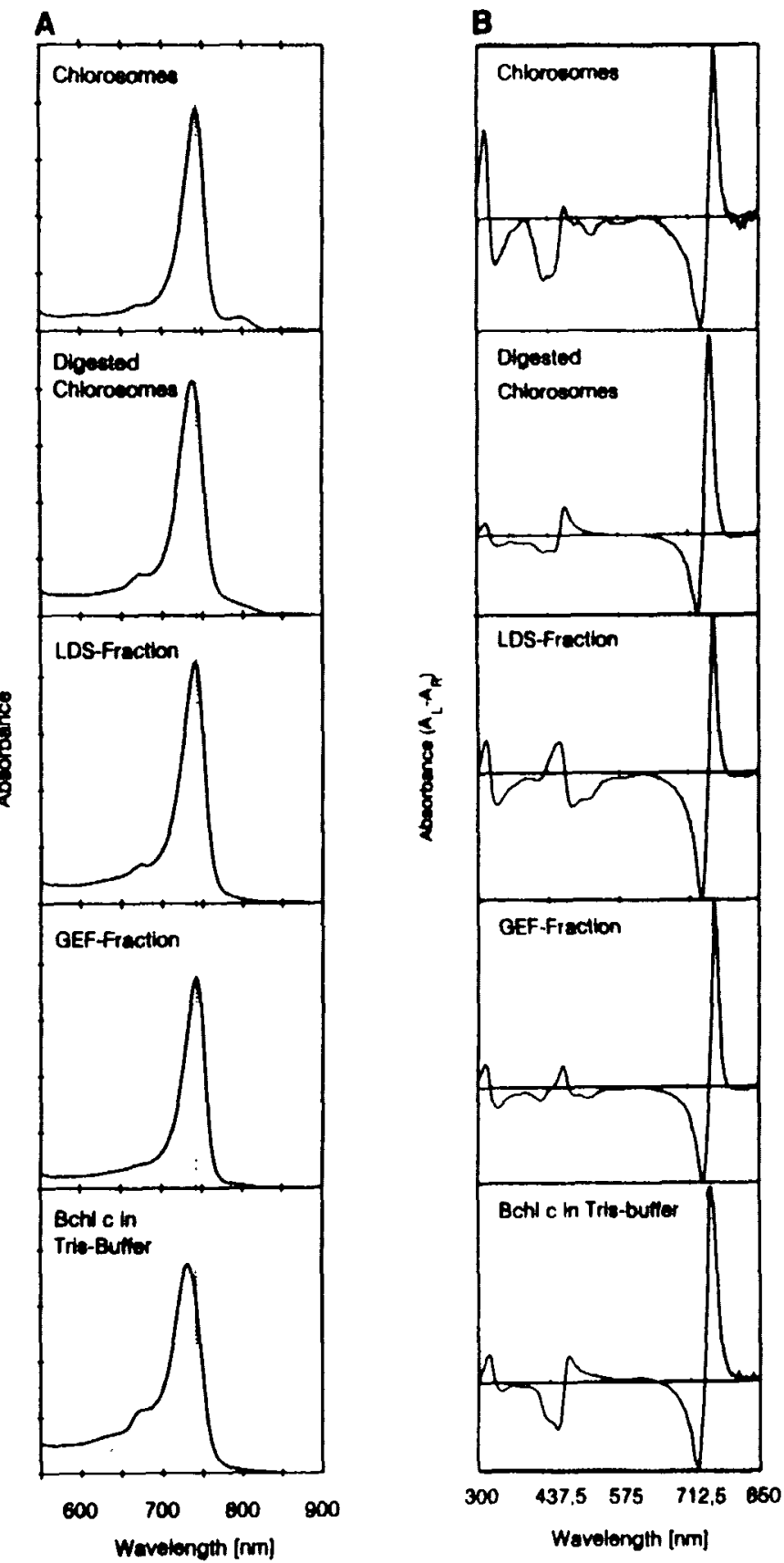

Fig. 9. Absorption (A) and CD (B) spectra of the five different Bchl-ccontaining fractions.

of the double CD band but, in particular, their rotational strengths which differ by more than an order of magnitude (Fig. 10). Proteolytically modified chlorosomes exhibited a striking 10 - 23-fold higher CD intensity (Fig. 10) indicating a dramatically stronger excitonic Bchl $c$ coupling and distinctly different organization as compared to native chlorosomes. In chlorosomes the magnitude of this amplitude appeared to depend to some extent on the growth conditions. Chlorosomes prepared from cells grown under 'low light' intensity exhibited an about twofold more intense $760 / 728-n m$ CD signal than chlorosomes isolated from cells grown under 'medium light' intensities. This difference might indicate a slightly stronger electronic pigment coupling in 'low light' chlorosomes which in turn might be related to a closer Bchl $c$ packing, but also 


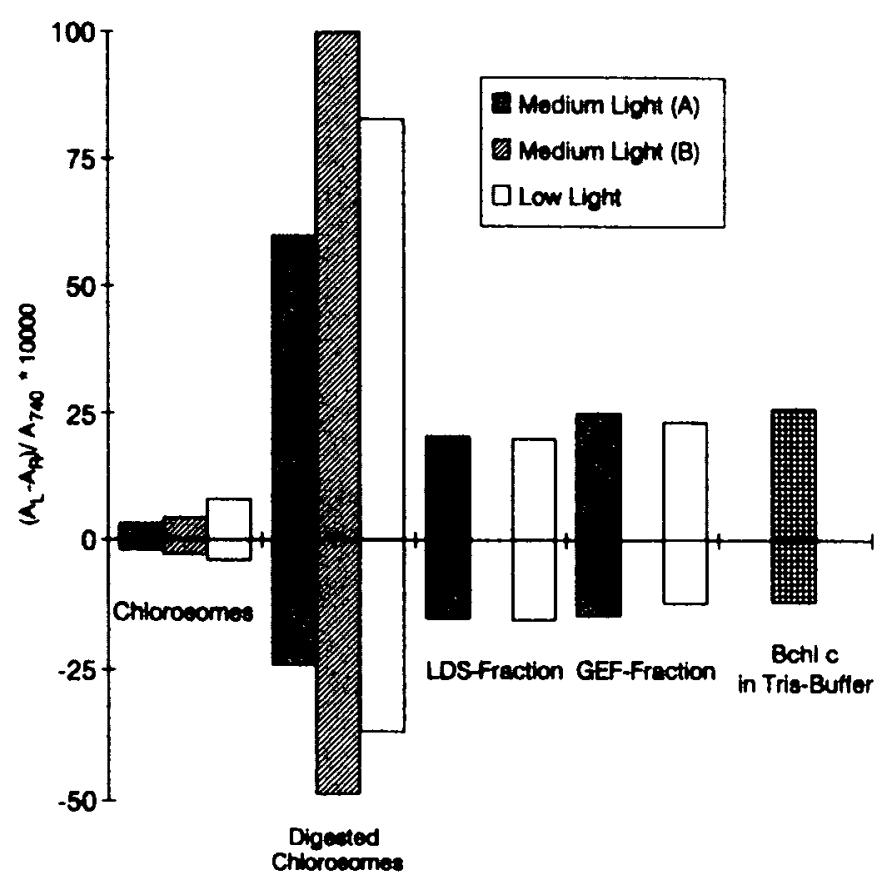

Fig. 10. Comparison of intensities of the positive $(760-\mathrm{nm})$ and negative (728-nm) $\mathrm{CD}$ bands in different Bcbl-c-containing fractions.

could be due to scattering effects. LDS treatment of chlorosomes increased the intensity of the 760/728-nm band by a factor of 6 for 'medium light' chlorosomes and 2.5 for 'low light' chlorosomes, so that the signal magnitudes were almost the same. Again, no signifcant differences in rotational strength between LDS 'chlorosomes' and GEF 'chlorosomes" were observed. In Bchl $c$ suspensions, the near infrared $\mathrm{CD}$ feature was considerably higher $(3-8$-fold, Fig. 10) than in chlorosomes but did not reach the magnitude of those in digested chlorosomes.

\section{DISCUSSION}

The results reported here, in particular the spectral sensitivity of the 740-nm absorption, provide strong evidence for the functional involvement of protein in the Bchl $c$ organization in chlorosomes of $C$. aurantiacus. Even though proteases purchased from different manufacturers were used for the experiments, the same results were obtained. The reproducibility of these observations indicate that the spectral change was a result of proteolysis and not due to a contaminating esterase activity which could have caused a pigment modification leading to a spectral shift. While these results were conclusive, the absence of a strict correlation between the decrease of the 740-nm absorption and the disappearance of the $M_{\mathrm{r}}-3700$ polypeptide upon proteolysis did not allow an unambiguous assignment of this protein as the Bchl-c-binding protein. The difficulties in assessing the correlation between these two kinetics were related to the possibility that the spectral product of the $740-\mathrm{nm}$ band after proteolytic treatment of chlorosomes could be a species with absorption properties similar to Bchl $c$ in Tris buffer. If this situation were true, the spectral degradation would indeed parallel the decrease of the $M_{\mathrm{r}}-3700$ polypeptide content.

The susceptibility of the two largest chlorosome proteins $\left(M_{r} 18000\right.$ and $\left.M, 11000\right)$ to proteolysis even at $40^{\circ} \mathrm{C}$ confirmed the results of Feick and Fuller [3] and their conclusion that these two polypeptides are exposed. The proteolysis of the $M_{\mathrm{r}}-3700$ polypeptide revealed a pronounced temperature dependency, e.g. below $45^{\circ} \mathrm{C}$ hardly any degradation was observed. This temperature dependency was probably related to the fluidity of the chlorosome envelope at the digestion temperature: below $45^{\circ} \mathrm{C}$ this layer was in a semi-solid state and, hence, the protease could not penetrate the envelope. This explanation agrees with the findings of Oelze and Fuller [36].

More evidence for the functional importance of the $M_{\mathrm{r}}$ 3700 polypeptide rests on a comparison of analogous proteins which have been isolated from chlorosomes of five different green sulfur bacteria [37]. Although C. aurantiacus is phylogenetically distantly related to these bacteria, there is still an overall amino acid sequence similarity of $30 \%$ (two regions are completely conserved); among the green sulfur bacterial strains, similarities of $85-100 \%$ were observed.

Whether the $C$. aurantiacus $M_{\mathrm{r}}-3700$ polypeptide is indeed arranged in an $\alpha$-helical conformation and binds seven Bchl $c$ molecules is not clear [16]. A different secondary structure with two helical and one short $\beta$-sheet region has been suggested by Gerola et al. [38]. Further arguments against the Wechsler et al. model are based on the absence, in Chloroflexus, of the amino acids thought to be pigment ligands and on picosecond polarized fluorescence measurements [39].

Our data should not neccessarily be interpreted as a $\mathrm{Bchl}$ c protein arrangement similar to antenna complexes of purple bacteria. It has already previously been suggested that Bchl $c$ is organized in a much more aggregated form compared to Bchl $a$ in purple bacteria antenna systems [3]. The in vitro Bchl c aggregation studies by Brune et al. $[9,28]$ also imply that oligomeric Bchl $c$ in chlorosomes could be reponsible for the observed absorption spectrum. The spectral properties of this aggregate, however, should be significantly influenced by the protein associated with the pigment (probably the $M_{\mathrm{r}}-3700$ polypeptide).

It has been recently proposed that the $M_{\mathrm{r}}-3700$ protein is a degradation product which accumulated within $48 \mathrm{~h}$ after chlorosome isolation [40]. Comparison of the chemically determined amino acid sequence of the mature $M_{\mathrm{r}}-3700$ protein with that deduced from the gene nucleotide sequence and the length of the mRNA [41] unambiguously showed that the proposal of Griebenow et al. was incorrect. The gene was transcribed as a small monocistronic message with a $3^{\prime}$ extension equivalent to 27 amino acids. Since the polypeptide is either co- or post-translationally modified during chlorosome biosynthesis, it was unlikely that the mature protein continued to accumulate $24 \mathrm{~h}$ after 'chlorosome' isolation.

Recently, the isolation and properties of "chlorosomes" free of baseplate (B 790) and protein" were described in a series of articles $[13,30,40]$. In principle, the isolation method was PAGE in the presence of LDS. We found the GEF 'chlorosomes' almost identical to our LDS - Bchl-c-fraction. The authors (Holzwarth and coworkers) have referred repeatedly to, but never published, electron micrographs of negatively stained GEF 'chlorosomes' as evidence for the structural integrity of their chlorosome preparation $[13,30,40]$. Fisher et al. [42] have published electron micrographs of Bchl $a$ and bacteriophytin $a$ oligomers showing that these polymers formed structures having dimensions and shapes very similar to that of chlorosomes.

With respect to a GEF 'chlorosome' preparation free of Bchl $a$ (B 790), our data clearly showed that the B 790 absorption is extremely sensitive to LDS and disappeared within 20 min after the addition of LDS. Hence, the absence of the 
790-nm absorbance was caused by detergent-induced degradation rather than a successful removal by the GEF procedure. Thus, the absence of B 790 fluorescence in GEF 'chlorosome' preparations [43] and SDS-treated chlorosome fractions [44] was not surprising.

Results of stationary and time-resolved fluorescence measurements have been used additionally as criteria for chlorosome integrity [43]. The interpretation of these data, however, does not appear to be clear cut. The decay-associated time-resolved fluorescence spectrum for GEF 'chlorosomes' differed significantly from sucrose density gradient chlorosomes in two aspects: (a) the presence of an additional kinetic component and (b) the overall faster energy transfer in GEF 'chlorosomes' [43]. Furthermore, SDS-treated sucrose density chlorosome preparations exhibited an unusually low yield of Bchl c fluorescence, despite the apparent absence of Bchl $a$ [44]. This 'quenching' and the corresponding decrease in fluorescence lifetime is characteristic for pigment aggregation and also has been measured in in vitro Bchl $c$ dimer and oligomer solutions $[9,12,45]$. According to Alfano et al. [46] and Mimuro et al. [12], the fluorescence lifetimes of oligomeric pigment decreases in proportion to the number of molecules in the oligomer.

It is known that pigment oligomerization is accompanied by the appearance of intense S-shaped CD bands in the nearinfrared wavelengths and is indicative of strong dipole-dipole interactions (exciton coupling) between two or more Bchl molecules in close proximity $[47,48]$. Accordingly, the CD data reported here indicate considerably stronger Bchl c coupling and, consequently, a different aggregation size or geometry of Bchl c molecules in LDS-treated chlorosomes, in $\mathrm{Bchl} c /$ Tris buffer solution and, reaching a maximum, in proteolytically modified chlorosomes as compared to native chlorosomes. This conclusion is consistent with (a) the occurrence of shorter fluorescence lifetimes of oligomeric Bchl $c$ in hexane $/ \mathrm{CH}_{2} \mathrm{Cl}_{2}$ or hexane/ $\mathrm{CCl}_{4}[9,28,45]$, (b) the-short lived $15 \mathrm{ps}) \mathrm{Bchl} \cdot($ fluorescence component [43] in GEF 'chlorosomes' and (c) the low fluorescence yield of Bchl $c$ in SDS-treated chlorosomes [44]. Highly aggregated pigments would indeed allow fast energy transfer and or radiationless internal quenching such as excimer quenching. Both processes could be responsible for the observed unusually short fluorescence lifetimes of oligomeric Bchl $c$.

Just recently Griebenow et al. [49] reported that $\mathrm{CD}$ spectra of different chlorosome preparations from $C$. aurantiacus showed variations in their sign of the S-shaped nearinfrared band. However, after carefully looking at the published spectra, we believe that these variations were far less pronounced than interpreted. The majority of the spectra (15 from 19) had identically shaped near-infrared bands, similar to ours. We have not seen variations in the C.D of our preparations but, rather, the spectrum seemed fairly distinct for each kind of preparation. It is, therefore, concluded that CD analysis is not as unreliable as suggested by Griebenow et al. [49].

In conclusion, the results presented here clearly verify that the degradation of protein, most likely the $M_{\mathrm{r}}-3700$ protein, affects the functional organization of Bchl $c$ in chlorosomes of C. aurantiacus. Treating chlorosomes with anionic detergents such as SDS, LDS or sodium lauroyl sarcosinate allows the preparation of Bchl $c$ fractions which retain native absorption properties, but creates a microenvironment for Bchl $c$ which is clearly different from that in chlorosomes. Furthermore, our data corroborate existing results, showing that the Bchl- $a$-free GEF 'chlorosomes' most likely consist of a detergent Bchl-c oligomer micelle.

This research was supported by a grant from the Deutsche Forschungsgemeinschaft (SFB 143). We would like to thank Dr. J. Shiozawa for helpful discussions and for critically reading the manuscript. R. F. thanks Prof. D. Oesterhelt for his support.

\section{REFERENCES}

1. Schmidt, K. (1980) Arch. Microbiol. 124, 21 - 31.

2. Feick, R. G., Fitzpatrick. M. \& Fuller, R. C. (1982) J. Bacteriol. 150,905-915.

3. Fcick. R. G. \& Fuller, R. C. (1984) Biochemistry 23, 3693-3700.

4. Staehelin, L. A., Golecki. J. R., Fuller, R. C. \& Drews. G. (1978) Arch. Microbiol. 119, 269-277.

5. Sprague, S. G., Staehelin, A. \& Fuller, R. C. (1981) J. Bacteriol. I47, 1032- 1039 .

6. Golecki, J. R. \& Oelze, J. (1987) Arch. Microbiol 148, 236-241

7. Betti, J. A., Blankenship, R. E.. Natarajan, R. V., Dickınson, L. C. \& Fuller, R. C. (1982) Biochim. Biophys. Acta 680. 194201.

8. Van Dorssen, R. J., Vasmel. H. \& Amesz, J. (1986) Photosınth. Res $9,33-45$.

9. Brune, D. C., King. G. H., Infosino, A.. Steiner, T., Thewalt, M L. W. \& Blankenship, R. E. (1987) Biochemistry 26, 86528658 .

10. Wittmershaus, B. P., Brune, D. C. \& Blankenship, R. E. (1988) in Photosynthetic light-harvesting sy'stems: organization and function (Scheer, H. \& Schncider, S., eds) pp. 543-554. Walter de Gruyter, Berlin.

11. Van Dorssen. J. R. \& Amesz, J. (1988) Photosynth. Res. 15.177189

12. Mimuro, M., Nozawa, T., Tamai, N., Shimada, K., Yamazaki I.. Lin, S., Knox, R. S., Wittmershaus, B. P.. Brune, D. C. \& Blankenship. R. E. (1989) J. Phys. Chem. 93, 7503-7509.

13. Holzwarth, A. R., Griebenow, K. \& Schaffner, K. (1990) Z. Naturforsch. 45c.203-206.

14. Miller, M., Cox, R. P. \& Gillbro, T. (1991) Biochim. Biophys. Acta 1057, $187-194$.

15. Smith, K. M.. Kehres. L. A. \& Fajer, J. (1983) J. Am. Chem. Soc. $105,1387-1389$.

16. Wechsler, T., Suter, F., Fuller, R. C. \& Zuber, H. (1985) FEBS Lett. 181, 173-178.

17. Drews, G. (1985) Microbiol Rev. 49,59-70.

18. Cogdell, R. J. (1986) in Encyclopedia of plant physiology, vol. 19 (Staehelin, L. A. \& Arntzen, C. J.. eds) pp. 252-259. SpringerVerlag. Berlin, Heidelberg, New York, Tokyo.

19. Zuber, H. (1986) in Encyclopedia of plant phystology, vol. 19 (Staehelin, L. A. \& Arntzen, C. J., eds) pp. 238-251, SpringerVerlag, Berlin, Heidelberg, New York, Tokyo.

20. Michel, H. (ed) (1990) Crystallisation of membrane protems, CRC Press, Boca Raton, FL.

21. Feick, R. G. \& Drews, G. (1978) Biochim. Biophys Acta 501, $499-513$.

22. Peters, J. \& Drews, G. (1983) FEMS Microbiol. Lett. 17. $235-$ 237.

23. Peters, J. \& Drews, G. (1984) J. Bacteriol. 158, 983-989.

24. Webster, G. D., Cogdell, R. J. \& Lindsay, J. G. (1980) Biochim. Biophys. Acta 591.321-330.

25. Scherz, A., Rosenbach, V. \& Fisher J. R. E. (1991) in Chlorophylls (Scheer, H., ed) pp. 237-268, CRC Press, Boca Raton, FL.

26. Katz, J. J., Bowman, M. K.. Michalski, T. J. \& Worcester D. L. (1991) in Chlorophylls (Scheer, H., ed) pp. 211-235, CRC Press, Boca Raton, FL.

27. Olson, J. M., Gerola, P. D., Van Brakel, (j. H., Meiburg, R. F. \& Vasmel, H. (1985) in Antennas and reaction centers of photosynthetic bacteria (Michel-Beyerle, M. E., ed) pp. 67-73, Springer-Verlag, Berlin.

28. Brune, D. C., Nozawa. T.\& Blankenship, R. E. (1987) Biochemistry $26,8644-8652$. 
29. Olson, J. M. \& Pedersen, J. P. (1988) in Photosynthetic lightharvesting systems: organization and function (Scheer, $\mathrm{H}$. \& Schneider, S., eds) pp. 365-373, Walter de Gruyter, Berlin.

30. Griebenow, K. \& Holzwarth, A. R. (1989) Biochim. Biophys. Acta 973, 235-240.

31. Eckhardt, A., Brunisholz, R., Frank, G. \& Zuber, H. (1990) FEBS Lett. 267, $199-202$.

32. Feick, R. G. \& Shiozawa, J. A. (1990) Anal. Biochem. 187, 205211.

33. Dottavio-Martin, D. \& Ravel, J. (1978) Anal. Biochem. 87, 362 365.

34. Laemmli, U. K. (1970) Nature (Lond.) 227, 680-685.

35. Shiozawa, J. A., Lottspeich, F., Oesterhelt, D. \& Fejck, R. G. (1987) Eur. J. Biochem. 180, 75-84.

36. Oelze, J. \& Fuller, R. C. (1983) J. Bacteriol. 155, 90-96.

37. Wagner-Huber, R., Brunisholz, R., Frank, G. \& Zuber, H. (1988) FEBS Lett. 239, 8-12.

38. Gerola, P. D., Hojrup, P. \& Olson, J. M. (1988) in Photosynthetic light-harvesting systems: organization and function (Scheer, H. \& Schneider, S., eds) pp. 129-139, Walter de Gruyter, Berlin.

39. Fetisova, Z. G., Freiberg, A. M. \& Timpmann, K. E. (1988) Nature $334,633-634$
40. Griebenow, K., Holzwarth, A. R. \& Schaffner, K. (1990) Z. Naturforsch. 45c, 823-828.

41. Theroux, S. J., Redlinger, T. E., Fuller, R. C. \& Robinson, S. J. (1990) J. Bacteriol. 172, 4497-4504.

42. Fisher, J. R. E., Rosenbach-Belkin, V. \& Scherz, A. (1990) Biophys. J. 58, $461-470$.

43. Holzwarth, A. R., Müller, M. G. \& Griebenow, K. (1990) J. Photochem. Photobiol. 5, 457-465.

44. Brune, D. C., Gerola, P. D. \& Olson, J. M. (1990) Photosynth. Res. 24, 253-263.

45. Causgrove, T. P., Brune, D. C., Blankenship, R. E. \& Olson, J. M. (1990) Photosynth. Res. 25, 1-10.

46. Alfano, A. J.. Lytle, F. E., Showell, M. S. \& Fang, F. K. (1985) J. Chem. Phys. 82, 758-764.

47. Gottstein, J. \& Scheer, H. (1983) Proc. Natl Acad. Sci. USA 80 , $2231-2234$

48. Sauer, K. (1972) Methods Enzymol. 24, 206-217.

49. Griebenow, K., Holzwarth, A. R., Van Mourik, F. \& Van Grondelle, R. (1991) Biochim. Biophys. Acta 1058, 194- 202. 
Copyright of European Journal of Biochemistry is the property of Blackwell Publishing Limited and its content may not be copied or emailed to multiple sites or posted to a listserv without the copyright holder's express written permission. However, users may print, download, or email articles for individual use. 